\title{
Reconstruction 0f Alquran Study With Social Linguistic Approach Method Amin Khulli
}

\author{
Bustami Saladin \\ Ushuluddin Faculty of UIN Mataram \\ saladinbustami@gmail.com
}

\begin{abstract}
In reconstructing the method of study of the Koran a person must have the ability of Arabic language and literary science as well as an appropriate and qualified methodology to be able to make understanding correctly more in answering social problems. In this context the role of the linguistic approach becomes important in interpreting social verses, both of which are very important in understanding the Qur'an. In understanding the Qur'an to answer social problems, it cannot be separated from one's understanding of the textuality of the verse and the context of social events. that happened at that time. That is why Amin al-Khîlî usesAl Qur'an study methods on social problems with a linguistic approach model
\end{abstract}

Keywords: Amîn al-Khûlî, Linguistic approach, social issues

\begin{abstract}
Abstrak: Dalam merekonstruksi metode studi al-Qur'ân seseorang harus memiliki kemampuan bahasa Arab dan ilmu kesastraan sekaligus metodologi yang tepat dan mumpuni untuk dapat melakukan pemahaman dengan benar lebih lebi dalam menjawab persoalan sosial kemasyarakatan. Dalam kontreks tersebut peran pendekatan linguistik menjadi penting untuk dalam menginterprestasikan ayat ayat sosial, kedua hal tersebut sangat penting dalam memahami al-Qur'ân Dalam memahami Al-Qur'an untuk menjawab persoalan sosial tidak terlepas dari pemahaman seseorang terahadap tekstualitas ayat dan kotekstualitas kejadian sosial yang terjadi pada waktu itu. Itulah sebabnya Amîn al-Khûlî menggunakan metode studi al Quran terhadap persoalan sosial dengan model pendekatan linguistik
\end{abstract}

Kata Kunci: Amîn al-Khûlî, Pendekatan Bahasa, Isu-isu Sosial 


\section{A. Preliminary}

In the design of Islamic study methodology, al-Qur'ân occupies a central and major position. Since it was revealed in the form of an oral discourse to Muhammad SAW, codified in one Uthmanic Manuscripts until the form that is known to Muslims today, various readings made by people on the Qur'an can be mapped into two major patterns, namely translation and interpretation, with various model, style and shape, ${ }^{1}$ sas well as in accordance with the dimensions of space and time (sociohistorical context) of the lives of the subjects who read it, so that in the next development, thousands or even tens of thousands of works of al-Qur'an are born according to the two patterns above with the aim of understanding the deepest message. These noble goals are oriented to re-formulating positive lines of wisdom according to contemporary needs and based on social and moral instructions contained in Islam, ${ }^{2}$

According to the tendency of each group to do so, regardless of differences in views that occur, both among conservative, traditionalist, progressive and modernist Islam.

However, 14 centuries is not a short time for the present generation to be able to realize the noble goal of understanding the deepest message of the Qur'an, even if it is almost impossible. Arkoun illustrated by illustrating that the text of the Qur'an which gave birth to many interpretive literature throughout the centuries from the beginning until now is like the geological layers of the earth, so that the current generation will not be able to penetrate into the events of the formation or first development (al-Hadats Ta'sîs al-Awwal) in a fresh and rich state, except by removing the geological layers and it is very difficult to do.

For this reason, according to Arkoun, the current generation is only able to reach the limits of knowing its reflective images and become their perspective in seeing all problems. Whereas on the other hand, the repertoire of interpretation of the Koran with all schools and schools

${ }^{1}$ Nasruddin Baidan, Metodologi Penafsiran Al-Qur'ân, (Yogyakarta: Pustaka Pelajar, 1998, Cet. I), h. 5-6

2 .Mazheruddin Siddiqi, The Quranic Concept of History, (Karachi: Islamic Research Institute, 1995), h.12 
according to Arkoun only "used" the Koran to develop other texts that could meet the needs and tastes of a particular time after the Koran, so that it exists by itself and for itself, with more various cultural contexts, social spheres and theological schools than the context of the Qur'an itself. $^{3}$ Based on Arkoun's perspective above, an actor of the study of the Qur'an must have Arabic language skills and a sensitive literary sense as well as an appropriate and qualified methodology to be able to conduct his studies correctly.

In this context the role of hermeneutics becomes important to carry out the task, because the two major patterns in understanding the Qur'an are hermeneutic activities that reflect certain cultural patterns and are always associated with the process of transforming messages, both oral and written to be conveyed to people who live in different world. ${ }^{4}$

The linguistic and literary approach in understanding the texts of the Koran in highlighting social and social issues in question is not limited to the mastery of various conventional Arabic linguistic disciplines, such as Nahw, Sharf, Fiqh al-Lughah, Balâghah (Ma'ânî, Bayân and Badî ') ), 'Arûdl wa al-Qawâfî, but how to apply these various classical treasures in the perspective and scope of social social life so that the Koran is not only viewed as a reading book but the Koran is viewed as a way of life in social issues. Each sub-discipline is complementary and becomes a science of assistance for the others. Especially as the language of the Koran, Arabic has special and typical specifications that are not possessed by other languages. One of the efforts to formulate the methodology of understanding or firmness of the hermeneutic of the text of the Qur'an in the context of answering social matters is the interpretation model initiated by Amin al-Khûlî, by JJG. Jansen is seen as the best representation of the linguistic and literary approaches in

${ }^{3}$ Mohammed Arkoun, Metode "Kritik Akal Islam" (Wawancara Arkoun dengan Hasyim Shalih), Jurnal UQ Edisi Khusus 5 Tahun UQ, No. 5 dan 6, Vol. V / 1994, h. 157-158.

${ }^{4}$ Komaruddin Hidayat, Memahami Bahasa Agama; Sebuah Kajian Hermeneutik, (Jakarta: Paramadina, 1996, cet. I), h. 14 
the interpretation of the Qur'an after the interpretation of al-Kasysyah al-Zamakhsyari. ${ }^{5}$

This paper is directed to explore the methodological implications of al-Qur'an's interpretation model Amin al-Khal in answering social problems

\section{B. A Little Biography Amîn al-Khûlî,}

Amîn al-Khûlî was born in Shûshâi on 1 May 1895 from a father named Ibrâhîm 'Abd al-Bâqî and mother Fâthimah Bint' Alî T mir alKhûlî. ${ }^{6}$ When he was 7 years old, he lived with his grandfather, Shaikh 'Alî T mir al-Khûlî in Cairo and took formal elementary education and studied Arabic grammatics, monotheism, fiqh and others. In 1907, he enrolled at the al-Qissûnî mosque madrasa and after graduating, he moved to the Utsmân Pasha Madrasa for 3 years and began to memorize the Qur'an. On the advice of his teacher, Shaykh 'Abdurrahma $>n$ Khaliffah, alKhûlî continued his studies at Madrasah al-Qadlâ' al-Syar'̂̂, the Jewish religious school that embodied the Muhammad Abduh movement. ${ }^{7}$ The majority of the teachers at the school led by Sa' ad Zaghlul were recruited from the alumni of the Universities of England and France, including a prominent figure 'thif Barakât, the teacher had a great influence on the character and thoughts of al-Khûlî. ${ }^{8}$

During the period 1915-1917, he was active in the Madrasah Ikhwa>n al-Shafa> with Abdul Wahhâb 'Azzam, Mahmûd Abû Bakr Hasan, Muhammad' Abdurrahman al-Judaylî, and Thâhâ Najâtî, as well as active in the world of literature and theater, so that in 1920, he was appointed as a staff at Madrasah al-Qadlâ 'al-Syar'î. Three years after this stipulation, al-Khûlî attended the religious meeting of counselors in Rome, Italy until 1926, having previously written a number of articles in journals published in Egypt, al-Muqtathaf and al-Hilal and read some

\footnotetext{
5 Anwa $>$ r al-Jundi, al-Muha $>$ fadhah wa al-Tajdi $>$ d fi $>$ an-Natsr al-'Arabi $>$ al-Mua>'shir fi Mi'at 'A>m, (Kairo: 1840-1940), h. 718-722.

${ }^{6} \mathrm{Sa}$ 'fa $>$ n Ka>mil, Ami $>$ n al-Khu $>$ li $>$ (Kairo: al-Hay'ah al-Misriyyah alA $>$ mmah li al-Kita $>$ b, 1982). h. 3-7

7 Sa'fa $>$ n Ka>mil, Ami>n al-Khu>li>, h 24

${ }^{8} \mathrm{Sa}$ 'fa $>$ n Ka>mil, Ami $>$ n al-Khu $>$ li $>$, h, 16
} 
Orientalist works such as Luigi Renaldo and Celestino Sciaparty sourced from al-Madi>nah al-'Arabiyyah Media. Then he moved to Berlin for a year to carry out the same task. While in Italy and Berlin, al-Khûlî learned Italian and German, ${ }^{9}$

In 1927, al-Khu>li> returned to Egypt, taught at al-Qadla> 'alSyar'î Madrasa and was a guest lecturer at the Ushu $>$ luddi $>$ n Theology Department at al-Azhar University and at Egyptian and Cairo universities since November 1928. At these two universities, al -Khu $>$ li $>$ developed his intellectual career in the fields of literature and Islamic studies, such as Arabic and al-Qur'an studies. Although not considered a productive writer, al-Khalil's work related to the methodology of the interpretation of the Koran often becomes a reference for many people until now, because it is seen as a design and construction of a new methodology, where in subsequent developments, the method was well applied by his student and wife, 'Aisyah' Abdurrahman Bint al-Sythi '. Subsequently, al-Khu>li was appointed professor of al-Qur'an studies at Cairo Giza University. This position ended when he guided doctoral dissertation Muhammad Ahmad Khalafallah in 1947. The thesis entitled al-Fann al-Qashashi $>$ fi $>$ al-Qur'an al-Kari $>m$ became a sharp debate among the scholars and became a great controversy regarding the historical historicity of the Qur' an ' about the concept of prophethood. Al-Azhar scholars blamed Khalafallah and Ami $>\mathrm{n}$ al-Khu $>\mathrm{li}>$ and called them both deniers and infidels, a few years later al-Khu $>\mathrm{li}>$ was fired and lost his job. ${ }^{10}$

Since 1940, al-Khu $>$ li $>$ has been a member of the Arabic academy committee, "Majma 'al-Lughah al-Arabiyah", along with HAR Gibb, $\mathrm{Mahmu}>\mathrm{d}$ Shaltu $>$ t, Ha $>$ mid Abdul Qa $>$ dir and others. This group was entrusted with carrying out the special task of compiling the al-Qur' $a>n$ dictionary, which was finally published under the title "Mu'jam Alfa $>$ dz al-Qur'a $>$ n al-Kari $>$ m". In this collection, al-Khul only completes 4

${ }^{9}$ Bint al-Sya $>$ ti', al-Tafsi $>$ r al-Baya $>$ ni $>$ li al-Qur'a $>$ n al-Kari $>$ m; Vol. I (Kairo: Da $>$ r al-Ma'rifah, 1972), h. 10-11

${ }^{10}$ F. Budi Hardiman, Melampaui Positivisme dan Modernitas, Diskursus Filosofis tentang Metode Ilmiah dan Problem Modernitas, (Yogyakarta: Kanisius, 2003, Cet. I), h. 48 
volumes from the letter Shad to Fâ 'because he died before completing his assignment. In 1956, al-Khul became the leader of a special group of Egyptian scholars who were interested in studying Arabic literature and published a monthly Arabic literature journal, "Majallat al-Adab", from March 1956 to death in 1966.

\section{Amin Al Khulli’s Linguistic Approach Model Towards Social Problems}

The method of interpreting the Qur'an which was conceived by al-Khul is detailed in his work entitled Madzâhib Tajdîd fî al-Nahw wa al-Balahghah wa al-Tafsir wa al-Adab. In it, Al-Khûlî explains the meaning of interpretation, the history of its growth and development process, its methodology, its attitude towards scientific interpretation of the verses of the Koran, its interpretation style, its processes and procedures as well as the offer of a social approach that is used in interpreting the verse Al-Qur'an

Etymologically, al-Khûlî interprets the word tafsîr as a process of expressing and constructing meaning (Kasyf al-Ma'nâ wa Ibânatuh). As for the terminology, interpretation is an explanation of the Word of God (Bayân Kalâm Allâh), or all information about the expression of the Qur'an and all its conceptions (al-Mubayyan li Alfâdz al-Qur'ân wa Mafhûmâtihâ). Basically, al-Khul starts from the idea that al-Qur'ân is the largest Arabic book and is within the scope of Arabic literary studies, so to study it, the language and literary approach occupies a very significant position.

For al-Khûlî, the concept is a critique of the most important goals of the interpretation of the Qur'an as Muhammad Abduh, namely as an effort to prove the guidance and grace of the Qur'an as well as an explanation of the wisdom of al-Tasyrî 'in matters of faith , morality, social and law. ${ }^{11}$

In history, al-Qur'ân has been proven successful in maintaining and preserving social existence in human life, so that the involvement

${ }^{11}$ Mansoer Pateda, Linguistik Terapan, (Flores: Nusa Indah, 1991, Cet. I), h. $23-24$ 
of al-Qur'ân in social studies is a necessity that crosses the boundaries of religion, race and community groups. For this reason, al-Qur'ân must be interpreted according to certain themes and problems as a whole by gathering the verses specifically and knowing the order of time of their descent, as well as the events underlying them, so that these interpretations produce more precise meanings and understandings.

The literary interpretation method (Manhaj al-Tafsîr al-Adabî) with the hermeneutic approach to social problems initiated by al-Khûlî offers two types of approaches and criticisms, namely: External Criticism (al-Khârijîi / Mâ Hawl al-Qur'ân) and Internal Criticism (al-Dâkhilî / Mâ Fî al-Qur'ân). Al-Qur'an study externally includes two things, namely: Studies that are specific and close to the Qur'an, and studies that are general and far from the Qur'an. Al-Khûlî classifies knowledge about the process of the descent of the Koran, its collection, how to read it and all things that have been known historically since the 6th century $\mathrm{AH}$ and are known as 'Ulam al-Qur'an' into specific study groups and close to the Qur'an.

The general external study of the Koran covers all matters relating to the material and meaningful environment, when the Koran comes down, is collected, written, read, memorized and conveyed to humans. The above aspects are oriented to the historical, cultural, religious, canonical and social dimensions in depth and the comparison between each dimension. In short, the study of the Koran externally involves two things, namely: first, the philological aspects (Tahqîq al-Nashsh), the determination of the text and the history of its birth and second, the socio-historical-georaphic setting that gave birth to the text and produced its meaning.

The Al-Qur'an Study Internally begins with a lexicographic study by discussing vocabulary (al-Mufradat), how meaning is constructed, how it affects the process of changing meaning between generations in various psychological and social dimensions and elements of the human race that experienced directly by the history of the development of Arabic, including the historical experience of Islamic dynasties, the role of Muslims in politics and culture and other aspects. If that is not possible, the context of the Koran can be used, namely how a word is 
used in various meanings by the Koran, according to the order in which the verses descend. In the internal study of the Koran, the interpreter must use the Nahw (Arabic Syntax) and Balâghah. Nahw (Arabic syntax) is used as a means to explain and limit the meaning and see the compatibility between the meanings of different readings in a verse or meeting point of the use of words that are similar in the Qur'an in a single unified whole. Whereas Balagha is a literary-artistic binocular that seeks to uncover the literal beauty in the Qur'anic stylistica, which is a characteristic characteristic of the structure of the Arabic language.

If the interpretation methodology using the social approach is used, furthermore, it will open up the dynamic methodology from the subject dimension to the object dimension and from the object dimension to the subject dimension.

The subject is the interpreter as well as the reader of the Koran who, with the linguistic and literary approach, tries to see the Koran as the Largest Arabic "Writing" and as a holistic unity objectively, so that in this case the Koran function as Object I. Then, Object I gives birth to a variety of new objects in the form of branches and various new disciplines, including the psychological dimensions of the interpreter and reader, such as how the interpreter and reader feel when reading the Qur'an, what are spiritual experiences and social perceived and other

The process creates a movement towards the subject area, that is, the subject of the interpreter and the reader, including how the subject of the interpreter and reader positions the Qur' an as a guide, guide and guide for their social role in daily life.

Thus, the interpreter and reader in the al-Khûli hermeneutic cycle above occupy a new position that is different from its initial position. The hermeneutic pattern which is an integration between objective and subjective dimensions is in line with the Hermeneutics Schleiermacher and Dilthey models on one side and Gadamer on a different side. Schleiermacher and Dithey's romantic hermeneutics moves in the direction of reproductive identification, because they try to bring back the author's thoughts, feelings and will through empathy and reconstruction, while Gadamer states otherwise, that the interpreter must allow himself 
to clash with the author in order to enrich understanding with elements that unexpected. ${ }^{12}$

One of the lessons that can be drawn from the methodology of the interpretation of the Qur'ân initiated by Al-Khûlî is that the process of scientific codification originating from the Qur'ân has been able to be developed continuously without recognizing stopping points, according to scientific characteristics. in general. The scientific treasure can be used again as a perspective to study the Koran in order to understand it and explore its meaning even more, because the Koran will never dry up or run out of new meaning when we interpret it from a variety of possible perspectives. The deduction method that applies in the process of codifying Islamic scholarship from the Qur'an presupposes that the Qur'an is the main source followed by various Islamic disciplines below.

With the application of al-Khûlî's interpretation method, the deduction thinking model implicitly gets emphasis to continue with the induction method, namely by using Arabic language disciplines as one of the Islamological disciplines that become al-Khûlî's expertise in understanding and interpreting the Qur'an ' and make it as an object of study. The above processes and procedures can be simply described in the following scheme:

As has been understood, that when in its historical development, Islamic disciplines were born from the womb of the Koran then the Koran functions as the main source subject. In subsequent developments, Islamic sciences have historically developed their respective wings independently and independently, so that it seems as if it separates and is able to stand alone separately from the Qur'an which is its main source. Kalam, Tasawwuf, Fiqh and Philosophy are only examples of the plurality of the development of Islamology, each of which has a specific and typical methodology, systematic and theoretical approach to be used again to see, understand and interpret the message of the Qur'an, so at that moment, the Qur'an plays a totally different function from before,

${ }^{12}$ Mudji Sutrisno dan F. Budi Hardiman (ed.), Para Filsuf Penentu Gerak Zaman, (Yogyakarta: Kanisius, 2000, cet. IV), h. 75-79 
Ideally, the process and procedure for the development of Islamology above can be further explained with the following circular development patterns.

The schema of scientific development above is an ideal process of Islamic scientific development and must run continuously in a circular pattern without recognizing stopping points. Everything comes from the Qur'an which gave birth to various Islamic disciplines, such as Fiqh 1 (Islamic Law). Then, the Islamic discipline is applied and applied in the lives of the people, to manifest in a practice and display its own methodology, theoretical approaches and systematics.

In subsequent developments, the methodology, theoretical and systematic approach to science is used in understanding and capturing the message of the Qur'an as one of the development of Islamic studies, so that Islamic studies will continue to grow richer, without forgetting its historical roots and primary sources. After that, al-Qur'ân as a closed corpus can be re-interpreted based on the development of humanity's historicity that occurs to re-create new Islamic disciplines, such as Fiqh 2 in the above scheme, and continue to continue the development process in a sustainable and sustainable manner without knowing the point stop

Historically, what was done by al-Kh dilakukanlî can be interpreted as the reactualization of classical treasures based on modernity, because the basis of scientific methodology used is an old theory formulated by Arabic scientists and linguists in the past, including various works of Tafsir al-Qur ", which he criticized. However, the methodological resystematization that was initiated by al-Khîlî in the study of al-Qur'ân enables the classical scientific treasures to experience reactualization, so as to be able to answer the various demands of the times and scientific problems. Jansen praised it as a clean practice of various theological interests.

\section{Reconstruction of Al-Qur'an Study Methodology with Social lingoic Approach}

Before the description of the application of applied linguistics ala al-Khûlî is conveyed as a methodological implication of the method of interpreting the Koran that was initiated, it is necessary to explain the 
definitions and applied social objects and where the meeting points between these linguistic sub-disciplines with social approaches are contextual in the study of al-Qur'ân initiated by al-Khûlî. Basically, the terminology of applied linguistics has been known in various major languages of the world, such asangewandte Sprachwissenschaft(German), Applied Linguistics (American and English), Linguistique Appliquee (French), and 'Ilm al-Lughah al-Tathbîqiyyah (Arabic), although some linguists disagree with the use of the term. Spolsky, for example, agreed to use the term educational linguistics to broaden the scope of this study, because applied linguistics also studies translation, lexicography, language planning and other aspects related to the application of linguistics itself.

Among the many definitions coined by experts, there are at least two representative definitions, namely:

"Collective term for various applications of linguistics (and phonetic) scholarship to related practical fields (Hartmann and Stork)".

"Applied linguistics is the utilization of the knowledge of the nature of language achieved by linguistic research for the improvement of the efficiency of some practical tasks in which language is a central component (Corder)"13

The two definitions above are considered representative because they connect language tendencies with the practical areas of users and speakers in a functional circle. From the two, we can also determine the applied linguistic object, namely language in relation to practical needs, including various languages, such as phonology, morphology, syntax, semantics and discourse. In its four congresses, the International Applied Linguism Organization (AILA / Association Internationale de Linguistique Applique) has formulated the fields within the scope of this linguistic sub-discipline, where basically, these sub-disciplines are closely related to psychology, sociology and language teaching methods.

${ }^{13}$ Nashr Hâmid Abu $>$ Zayd, al-Nashsh al-Sulthah al-Haqi>qah: al-Fikr alDi $>$ ni $>$ Bayn Ira $>$ dat al-Ma'rifah wa Ira $>$ dat al-Haymanah, (Beiru>t: al-Markaz alTsaqâfî̀ al-'Arabi>, 1995). 
In the Arabic language itself, terminology 'Ilm al-Lughah alTathbîqiyyahless well known and popular, so therefore not so much attention. However, what al-Khûlî had initiated with the interpretation method as explained above is a brilliant innovation that differs from the applied linguistic paradigm used by western languages (German, French and English) and can become an interdisciplinary meeting point. Apart from the fundamental structure of the interpretation methodology that positions the Qur'an as the largest Arabic text, the literary interpretation model (al-Manhaj al-Adabî) al-Qur'an is oriented to al-Tafsir al-Nafsî (Psychological Interpretation) and al- Tafsîr al-Ijtimâ'î (Sociological Interpretation), so that al-Khûlî can be declared as a pioneer of the application of applied Arabic linguistics in the field of interpretation of sacred texts (read: Tafsir al-Qur'ân), ${ }^{14}$

Henry Guntur Tarigan said that changing the syntactic picture of sentences into phonetic and semantic terms in language activities can play interpretive functions, so that interpretation work as hermeneutical activities that also contain phonological and semantic language perian can be seen as part of the linguistic realm in social applied

When al-Khûlî uses an objective approach (al-Mawdlû'î) based on the framework of the literary method (al-Manhaj al-Adabî) in interpreting the Qur'an, developing the methodology of interpretation into internal and external areas as described in the chart above. is a reflection of the use of various Arabic linguistic rules in applied areas. Mapping the internal and external fields above is indeed still open to be sued, but the innovation should be appreciated critically.

From a typical Arabic linguistic point of view, the two studies are the development of the scope of studies towards' Ilm al-Lughah alWadzîfiyyah (Functional Linguistics), both in the al-Nahw al-Wadzîfî region (Functional Syntax) and the al-Sharf al-Wadiz alfiyah region -Wadzîfî (Functional Morphology), because it is a functionalization of Arabic linguistic rules. Moreover, when the methodological estuary $87-116=$

${ }^{14}$ Henry Guntur Tarigan, Psikolinguistik, (Bandung: Angkasa,1985, Cet. I), h. p. $87-116$

Henry Guntur Tarigan, Psycholinguistics, (Bandung: Angkasa, 1985, Cet. I), 
states that the literary method (al-Manhaj al-Adabî) in interpreting the Qur'an produces al-Tafsîr al-Nafsî (Psychological Interpretation) and al-Tafsîr al-Ijtimâ'î (Sociological Interpretation).

The idea of al-Tafsîr al-Nafsî (Psychological / Psychological Interpretation) was born because of the assumption of the relationship between the use of the knowledge of Balâghah in the interpretation of the Qur'ân with Psychology (Psychology of the Soul). The thought of an individual's awe towards al-Qur'an (al-I'jâz al-Nafsî li al-Qur'ân) presupposes a discipline about the secrets of the human psyche in the area of al-Qur'an's religious communication and the dialectics of its creed, including how the Koran is sowing peace in the heart and feelings, fostering faith and producing this positive influence throughout human generations. The al-Tafsîr al-Nafsî model (Psychological / Psychological Interpretation) stands on a solid foundation in the relationship between the art of speech (al-Fann al-Qawlî) and the human soul (al-Nafs alInsâniyyah). ${ }^{15}$

As for the idea of al-Tafsîr al-Ijtimâ'î (Social Interpretation) alQur'ân departs from the understanding of al-Khûlî with the thought of its predecessor, Muhammad 'Abduh in the Muqaddimah Tafsîr al-Fihtah, which states that the interpretation of al-Qur'ân requires the existence of knowledge in the form of knowledge about the state (ahwâl) of humans, their development and the role they play.

The above description clearly shows that the Arabic linguistic rules summarized in various languages have been used by al-Khûlî in applied areas, without leaving the Arabic Linguistic characteristics and privileges (I'jâz) of the Qur'an as revelations of God and the holy books. Muslims.

${ }^{15}$ Abdul Chaer dan Le onie Agustina, Sosiolinguistik; Perkenalan Awal, (Jakarta: Rineka Cipta, 1995, Cet. I), h.1-2. 


\section{Bibliography}

Al-Râghib al-Ishfahânî, al-Mufradât fî Gharîb al-Qur'ân

Amîn al-Khûlî, Madzâhib Tajdîd fỉ al-Nahw wa al-Balâghah wa al-Tafsîr wa al-Adab (Beirut: Dâr al-Ma'rifah, 1961, cet. I)

Ami $>$ n al-Khu>li, Mu'jam alFa $>d z$ al-Qur'a $>n$ al-Kari $>m$, Vol. IV (Kairo: Da $>$ r al-Kitâb al-'Arabi $>$ li al-Thiba>'ah wa al-Nasyr, 1967)

Anwa $>$ r al-Jundi, al-Muha $>$ fadhah wa al-Tajdi $>d$ fi $>$ an-Natsr al'Arabi> al-Mua> shir fi Mi'at 'A>m, (Kairo: 1840-1940)

Bint al-Sya $>$ ti', al-Tafsi $>$ ral-Baya $>n i>$ li al-Qur'a $>n$ al-Kari $>m$; Vol. I (Kairo: Da>r al-Ma'rifah, 1982)

F. Budi Hardiman, Melampaui Positivisme dan Modernitas, Diskursus Filosofis tentang Metode Ilmiah dan Problem Modernitas, (Yogyakarta: Kanisius, 2003, Cet.1)

Ibn Mandhûr al-Mishrî, Lisân al- 'Arab

JJG. Jansen, Diskursus Tafsir al-Qur'ân Modern, (Terj.) Hairus Salim dan Syarif Hidayatullah, (Yogyakarta: Tiara Wacana, 1997, cet. I)

Mansoer Pateda, Linguistik Terapan, (Flores: Nusa Indah, 1991, Cet. I)

Nashr Hâmid Abu> Zayd, al-Nashsh al-Sulthah al-Haqi>qah: al-Fikr al-Di>ni> Bayn Ira $>$ dat al-Ma'rifah wa Ira $>$ dat al-Haymanah, (Beiru>t: al-Markaz al-Tsaqâfî al-'Arabi>, 1995).

Roy J. Howard, Hermeneutika; Wacana Analitik, Psikososial dan Ontologis, (Terj.) Kusmana dan MS. Nasrullah, (Bandung: Nuansa, 2001, cet. II)

Sa'fa $>$ n Ka $>$ mil, $A m i>n$ al-Khu>li $>$ (Kairo: al-Hay'ah al-Misriyyah al-A $>$ mmah li al-Kita $>$ b, 1982) 